\title{
Prevalence of antibodies against SARS-CoV-2 according to socioeconomic and ethnic status in a nationwide Brazilian survey
}

\author{
Bernardo L Horta ${ }^{1}$, Mariângela F Silveira ${ }^{1}$, Aluísio J D Barros ${ }^{1}$, Fernando C Barros ${ }^{1}$, \\ Fernando P Hartwig ${ }^{1}$, Mariane S Dias ${ }^{1}$, Ana M B Menezes ${ }^{1}$, Pedro C Hallal', Cesar G Victora ${ }^{1}$
}

Suggested citation Horta BL, Silveira MF, Barros AJD, Barros FC, Hartwig FP, Dias MS et al. Prevalence of antibodies against SARS-CoV-2 according to socioeconomic and ethnic status in a nationwide Brazilian survey. Rev Panam Salud Publica. 2020;44:e135. https://doi.org/10.26633/RPSP.2020.135

ABSTRACT Objectives. To investigate socioeconomic and ethnic group inequalities in prevalence of antibodies against SARS-CoV-2 in the 27 federative units of Brazil.

Methods. In this cross-sectional study, three household surveys were carried out on May 14-21, June 4-7, and June 21-24, 2020 in 133 Brazilian urban areas. Multi-stage sampling was used to select 250 individuals in each city to undergo a rapid antibody test. Subjects answered a questionnaire on household assets, schooling and self-reported skin color/ethnicity using the standard Brazilian classification in five categories: white, black, brown, Asian or indigenous. Principal component analyses of assets was used to classify socioeconomic position into five wealth quintiles. Poisson regression was used for the analyses.

Results. 25025 subjects were tested in the first, 31165 in the second, and 33207 in the third wave of the survey, with prevalence of positive results equal to $1.4 \%, 2.4 \%$, and $2.9 \%$ respectively. Individuals in the poorest quintile were 2.16 times $(95 \%$ confidence interval $1.86 ; 2.51)$ more likely to test positive than those in the wealthiest quintile, and those with 12 or more years of schooling had lower prevalence than subjects with less education. Indigenous individuals had $4.71(3.65 ; 6.08)$ times higher prevalence than whites, as did those with black or brown skin color. Adjustment for region of the country reduced the prevalence ratios according to wealth, education and ethnicity, but results remained statistically significant.

Conclusions. The prevalence of antibodies against SARS-CoV-2 in Brazil shows steep class and ethnic gradients, with lowest risks among white, educated and wealthy individuals.

Keywords $\quad$ Epidemiology; coronavirus infections; surveys and questionnaires; social inequity; Brazil.

The COVID-19 pandemic is hitting Latin American countries with great intensity. As of 16 September 2020, Brazil is the second country in the world, after the United States, in the absolute number of deaths (https:/ / coronavirus.jhu.edu/ map.html). Over 1000 deaths continue to occur on most days (https:/ / covid.saude.gov.br).
In Brazil, prominent COVID-19 cases, including state governors and more recently President Jair Bolsonaro (https: / / www. bbc.com/news/world-latin-america-53319517), led to a disseminated impression that the epidemic affects Brazilian society as a whole, without distinction of class or ethnic group. If true, this finding would be in sharp contrast with data from high-income

\footnotetext{
1 Universidade Federal de Pelotas, Pelotas, Brazil. $\square$ Bernardo L Horta, blhorta@gmail.com
} 
countries, where the pandemic is disproportionally affecting ethnic minorities and poor populations (1). In the United States (https://www.nytimes.com/interactive/2020/07/05/ us / coronavirus-latinos-african-americans-cdc-data.html), African-Americans and Latinos are suffering from higher disease incidence and mortality than whites, according to reported cases. A study carried out in the Oxford Royal College of General Practitioners Research and Surveillance Centre network observed that black people and those living in the more deprived areas were more likely to test positive for SARS-CoV-2 (2). Another study in the United Kingdom (3) reported that non-white ethnicity and higher deprivation scores were strongly associated with increased COVID-19 mortality. In contrast, the large national surveys carried out in Spain did not find either nationality or education as risk factors for the presence of antibodies against SARS-CoV-2 (4).

We were only able to locate a single study of ethnic or social inequalities in COVID-19 in low- or middle-income countries. Baqui et al (5) described that in Brazil, COVID-19 hospital case-fatality was higher among individuals classified with black or with mixed ancestry, compared to whites (5). A commentary on this publication argued, without providing new data, that living conditions of Brazil's poor would make them more vulnerable to COVID-19 morbidity and mortality (6). Their study did not include a sufficient number of indigenous individuals for analyses.

We were unable to locate any population-based study from low or middle-income countries on social and ethnic inequalities in COVID-19 morbidity or mortality. The present analyses were aimed at assessing socioeconomic and ethnic group inequalities in prevalence of antibodies against SARS-CoV-2 in 133 sentinel cities throughout Brazil, as part of the EPICOVID-19 study (www.epicovid19brasil.org).

\section{METHODS}

In this cross-sectional study, three population-based repeated serological surveys were carried out in 133 Brazilian sentinel cities in Brazil's 27 federative units. The cities included Brasilia, 26 state capitals and the largest cities in each of the country's intermediate regions, as defined by the Brazilian Institute of Geography and Statistics (IBGE). In each city, 25 urban census tracts were selected with probability proportionate to size, and 10 households were randomly sampled in each tract. In each sampled household, all residents were listed, and one was randomly selected to be tested. If the selected individual refused to provide a blood sample, a second household member was randomly selected. If this person also refused, the interviewers moved on to the next household to the right of the one that had been originally selected. The next household to the right was also selected in case of absent residents. In the present manuscript, we pooled the data from the three survey waves that took place on May 14-21, June 4-7, and June 21-24, 2020. With 250 individuals per city, the margins of error (approximately two standard errors) for estimating prevalence figures of $2 \%, 5 \%$ and $10 \%$ are respectively $1.77,2.70$, and 3.79 percent points, and at national level, with total sample size of 33250 , the corresponding margins of error are $0.15,0.24$ and 0.33 .

The WONDFO SARS-CoV-2 Antibody Test (Wondfo Biotech Co., Guangzhou, China) was used to evaluate the presence of antibodies for SARS-CoV-2, using finger prick blood samples. At the time of the first survey, this was the only test available in the country in large numbers, and over 100000 tests were provided to the study by the Ministry of Health. The test detects immunoglobulins of both IgG and IgM isotypes specific to SARS-CoV-2 antigens in a lateral flow assay. The assay reagent consists of colloidal gold particles coated with recombinant SARS-CoV-2 antigens. Following the introduction of the blood sample, reactive antibody:antigen:colloidal gold complexes, if present, are captured by antibodies against human IgM and IgG present on the "test" (T) line in the kit's window, leading to the appearance of a dark-colored line. Valid tests are identified by a positive control line $(\mathrm{C})$ in the same window. If this control line is not visible, the test is deemed non-conclusive, which is uncommon.

The rapid test underwent independent validation studies that used RT-PCR as the gold standard. According to the manufacturer, it has a sensitivity of $86.4 \%$ and specificity of 99.6\% (https: / / en.wondfo.com.cn/product/wondfo-sars-cov2-antibody-test-lateral-flow-method-2/). A validation study carried out by the National Institute for Quality Control in Health (INCQS, Oswaldo Cruz Foundation, RJ, Brazil) showed a sensitivity of $100 \%$ and specificity of $98.7 \%$. Whitman et al evaluated 10 different lateral flow assays (7) and reported that the Wondfo test had a sensitivity of $81.5 \%$ and specificity of $99.1 \%$. A validation study carried out by our research group observed a sensitivity of $77.1 \%$ and specificity of $98.0 \%(8)$. By pooling the results from the four validation studies, weighted by sample sizes, sensitivity is estimated at $84.8 \%$ (95\% CI $81.4 \% ; 87.8 \%)$ and specificity at $99.0 \%$ (95\% CI $97.8 \%$; 99.7\%) (8).

Participants answered short questionnaires including sociodemographic information (sex, age, schooling, skin color, household size and household assets), COVID-19-related symptoms, use of health services, compliance with social distancing measures and use of masks. Due to the presence of widespread multiethnic population, the official Brazilian classification of ethnicity recognizes five groups, based on the question: "How do you classify yourself in terms of color or race?" The five response options are "white", "brown" ("pardo" in Portuguese), "black", "yellow (Asian)" and "indigenous". Interviewers were instructed to check the "yellow" option when the respondent mentions being of Asian descent, and "indigenous" when any of the multiple first nations are mentioned. The "brown" category reflects mixed ancestry including European, African and/or indigenous backgrounds. This system is endorsed by the Afro-descendants movement, which advocates for disaggregation of all national statistics to raise their visibility (9). Socioeconomic position was assessed using a wealth index derived through principal component analyses of household assets (10). The first component was divided into quintiles. Achieved schooling was recorded as the highest grade completed successfully.

Field workers used tablets to record the full interviews, register all answers, and photograph the test results. The questionnaire was applied before the test result was disclosed to each participant. Inconclusive tests were repeated, and 35 subjects presented a non-conclusive result in the second test, which were treated as missing values. All positive or inconclusive tests were read by a second observer, as well as $20 \%$ of the negative tests. 
Interviewers were tested and found to be negative for the virus and were provided with individual protection equipment that was discarded after visiting each home.

We used Stata 15 for the analyses. Proportions of positive tests according to region, sex, wealth quintiles, achieved schooling and skin color were compared using the chi-squared test. For ordinal variables, both in bivariate and multivariate analyses, we estimated the p-value for linear trend and for heterogeneity, and presented the one with the lower $\mathrm{p}$-value. We also stratified the analyses of seroprevalence according to socioeconomic variables by region of the country (North; Northeast; Southeast; South and Center-West), using Poisson regression with robust variance to estimate prevalence ratios. All analyses controlled for the cluster-sampling design using svy prefix.

Ethical approval was obtained from the Brazilian's National Ethics Committee (process number CAAE 30721520.7.1001.5313), with written informed consent from all adult participants; for minors, written consent was provided by parents or caregivers, and assent forms were also signed by the child or adolescent (provided that they were literate). The dataset is stored in anonymous form. Positive cases were reported to the municipal COVID-19 surveillance systems.

\section{RESULTS}

In the three waves of the seroprevalence survey, 89397 subjects were tested and 35 individuals with inconclusive test results in the test and retest were excluded from the analyses. Therefore, in the present study we evaluated 89362 subjects. The response rates were $54.4 \%, 52.6 \%$ and $55.6 \%$ in the three waves, mainly due to the fact that the whole family was away from home when the visit took place. The prevalence of positive results was $1.4 \%, 2.4 \%$, and $2.9 \%$ in the first, second and third surveys, respectively.

Table 1 shows that the proportion of males and young subjects in the studied population was below what was expected on the basis of the national population. Concerning skin color, most of the studied subjects reported being mixed (brown) or white and only $1.4 \%$ self-identified as indigenous. The proportion of subjects who reported being white was lower than the national estimates.

In the three phases of the study, there were 2064 positive tests $(2.31 \%)$ among the 89362 subjects with valid test results. Table 2 shows that the proportion of positive tests was higher in the North region $(6.7 \%)$, whereas in the Southern region only $0.2 \%$ of the studied subjects had a positive test.

Results for unadjusted analyses, and analyses with adjustment for age and sex, were very similar. Antibody prevalence was inversely associated with wealth quintiles; compared to the wealthiest, the poorest were about twice as likely to present antibodies against SARS-CoV-2. For schooling, the association was not linear, but subjects with 12 or more years of schooling were less likely to present positive tests than any of the other groups. The largest prevalence ratio were observed in the comparison between indigenous and white individuals, with a near five-fold ratio. Whites were less likely to test positive than any ethnic group, followed by Asians.

Because the proportion of individuals with antibodies against SARS-CoV-2 was higher in the Northern (Amazon) region, where indigenous and poor populations are concentrated, we carried out additional analyses with further adjustment for the
TABLE 1. Distribution of the study sample according to socioeconomic and demographic characteristics

\begin{tabular}{|c|c|c|c|}
\hline & \multicolumn{2}{|c|}{ Study sample } & \multirow{2}{*}{$\begin{array}{c}\text { Brazilian population } \\
2019(\%)\end{array}$} \\
\hline & Number & $\%$ & \\
\hline \multicolumn{4}{|l|}{ Region } \\
\hline North & 16013 & 17.9 & 8.8 \\
\hline Northeast & 26809 & 29.9 & 27.2 \\
\hline Southeast & 21860 & 24.5 & 42.1 \\
\hline South & 14888 & 16.7 & 14.3 \\
\hline Center-West & 9792 & 11.0 & 7.8 \\
\hline \multicolumn{4}{|l|}{ Sex } \\
\hline Male & 37309 & 41.8 & 51.7 \\
\hline Female & 52053 & 58.2 & 48.3 \\
\hline \multicolumn{4}{|l|}{ Age (years) } \\
\hline$\leq 9$ & 4263 & 4.8 & 12.9 \\
\hline $10-19$ & 8024 & 9.0 & 15.3 \\
\hline $20-39$ & 27485 & 30.8 & 33.2 \\
\hline $40-59$ & 28402 & 31.7 & 24.8 \\
\hline $60+$ & 21188 & 23.7 & 13.7 \\
\hline \multicolumn{4}{|c|}{ Color / ethnicity } \\
\hline White & 32383 & 37.0 & 45.2 \\
\hline Brown & 40088 & 45.9 & 45.1 \\
\hline Black & 11304 & 12.9 & 8.9 \\
\hline Asian & 2446 & 2.8 & 0.5 \\
\hline Indigenous & 1219 & 1.4 & 0.4 \\
\hline \multicolumn{4}{|c|}{ Schooling (in years) ${ }^{\mathrm{a}}$} \\
\hline$\leq 4$ & 14128 & 19.4 & \\
\hline $5-8$ & 13208 & 18.2 & \\
\hline $9-11$ & 28315 & 39.0 & \\
\hline$\geq 12$ & 17013 & 23.4 & \\
\hline \multicolumn{4}{|c|}{ Wealth quintiles } \\
\hline Poorest & 20976 & 23.5 & \\
\hline $2^{\text {nd }}$ & 16560 & 18.5 & \\
\hline $3^{\text {rd }}$ & 17325 & 19.4 & \\
\hline $4^{\text {th }}$ & 17262 & 19.3 & \\
\hline Richest & 17230 & 19.3 & \\
\hline Total & $89362^{b}$ & & \\
\hline
\end{tabular}

Source: prepared by authors from the results.

Subjects $<20$ years were excluded.
For Color/ethnicity, the total does not sum to 89362 because of missing data $(n=1922)$, and for wealth quintiles information was missing for 9 subjects. For schooling, information was missing for 4411 subjects.

five regions of the country. In these analyses, the prevalences of seropositivity were still lower in the richest quintile, but the magnitude of the prevalence ratio decreased. Indigenous individuals still showed higher prevalence than whites (prevalence ratio: $2.25 ; 95 \%$ CI $1.74 ; 2.91$ ), as did individuals classified as black or brown.

Table 3 shows that in the Northern region, in spite of the decrease in the magnitudes of the associations compared to the national analyses (Table 2), the inverse associations with wealth remained significant, and the higher prevalence among indigenous and brown subjects compared to whites also persisted. In the Northeastern region, seroprevalence was also inversely associated with wealth, but not with ethnicity. Prevalence for indigenous subjects were 2.27 times higher than for whites. In the remaining regions, where prevalence was low at the time of the surveys, we did not observe any clear pattern of association with wealth, but black and brown subjects had significantly higher risks than whites. Consistent results were observed for education in all regions, with lower risk for subjects with 12 or more years of schooling than for the other groups.

Table 4 shows that the even after controlling for region and socioeconomic status, the seroprevalence remained significantly higher among indigenous, brown and black subjects. 
TABLE 2. Prevalence of antibodies against SARS-CoV-2 according to socioeconomic and demographic characteristics

\begin{tabular}{|c|c|c|c|c|c|}
\hline & \multirow{2}{*}{$\begin{array}{l}\text { Number of positive } \\
\text { samples }\end{array}$} & \multirow[t]{2}{*}{ Seroprevalence (\%) } & \multicolumn{3}{|c|}{ Prevalence ratio $(95 \% \mathrm{CI})$} \\
\hline & & & Unadjusted & Adjusted for sex and age & Adjusted for sex, age, and region \\
\hline $\begin{array}{l}\text { Region } \\
\text { North } \\
\text { Northeast } \\
\text { Southeast } \\
\text { South } \\
\text { Center-West }\end{array}$ & $\begin{array}{r}1065 \\
776 \\
149 \\
31 \\
43\end{array}$ & $\begin{array}{c}\mathrm{p}<0.001^{\mathrm{b}} \\
6.7 \\
2.9 \\
0.7 \\
0.2 \\
0.4\end{array}$ & $\begin{array}{c}31.94(21.09 ; 48.38) \\
13.90(9.14 ; 21.14) \\
3.27(2.10 ; 5.11) \\
\text { Reference }(1) \\
2.11(1.28 ; 3.48)\end{array}$ & $\begin{array}{c}p<0.001^{\mathrm{b}} \\
33.26(21.94 ; 50.41) \\
14.15(9.30 ; 21.52) \\
3.27(2.10 ; 5.10) \\
\text { Reference }(1) \\
2.14(1.29 ; 3.52)\end{array}$ & \\
\hline $\begin{array}{l}\text { Schooling (years) } \\
\leq 4 \\
5-8 \\
9-11 \\
\geq 12\end{array}$ & $\begin{array}{l}326 \\
347 \\
722 \\
253\end{array}$ & $\begin{array}{c}\mathrm{p}<0.001^{\mathrm{c}} \\
2.3 \\
2.6 \\
2.6 \\
1.5\end{array}$ & $\begin{array}{c}1.55(1.31 ; 1.83) \\
1.77(1.49 ; 2.09) \\
1.71(1.49 ; 1.98) \\
\text { Reference }(1)\end{array}$ & $\begin{array}{c}p<0.001^{c} \\
1.84(1.54 ; 2.20) \\
1.90(1.61 ; 2.26) \\
1.71(1.48 ; 1.97) \\
\text { Reference }(1)\end{array}$ & $\begin{array}{c}p<0.001^{c} \\
1.46(1.24 ; 1.75) \\
1.72(1.46 ; 2.03) \\
1.46(1.27 ; 1.68) \\
\text { Reference }(1)\end{array}$ \\
\hline
\end{tabular}

Source: prepared by authors from the results.

a Subjects < 20 years were excluded

${ }^{\mathrm{b}}$ test for heterogeneity

$\checkmark$ test for linear trend

TABLE 3. Prevalence and prevalence ratio of antibodies against SARS-CoV-2 according to socioeconomic and demographic characteristics, stratified by region of the country

\begin{tabular}{|c|c|c|c|c|c|c|c|c|c|c|c|c|}
\hline & \multicolumn{12}{|c|}{ Results by region of the country } \\
\hline & \multicolumn{4}{|c|}{ North } & \multicolumn{4}{|c|}{ Northeast } & \multicolumn{4}{|c|}{ Southeast/South/Center-West } \\
\hline & \multirow[t]{2}{*}{$\mathrm{N}$} & \multicolumn{2}{|c|}{ Positive samples } & \multirow{2}{*}{$\begin{array}{l}\text { Unadjusted } \\
\text { prevalence ratio } \\
(95 \% \mathrm{CI})\end{array}$} & \multirow[t]{2}{*}{ N } & \multicolumn{2}{|c|}{ Positive samples } & \multirow{2}{*}{$\begin{array}{l}\text { Unadjusted } \\
\text { prevalence ratio } \\
(95 \% \mathrm{Cl})\end{array}$} & \multirow[t]{2}{*}{$\mathrm{N}$} & \multicolumn{2}{|c|}{ Positive samples } & \multirow{2}{*}{$\begin{array}{c}\text { Unadjusted } \\
\text { prevalence ratio } \\
(95 \% \mathrm{Cl})\end{array}$} \\
\hline & & N & $\%$ & & & $N$ & $\%$ & & & $\mathrm{~N}$ & $\%$ & \\
\hline Wealth quintiles & \multicolumn{4}{|c|}{$\mathrm{p}=0.03^{\mathrm{b}}$} & \multicolumn{4}{|c|}{$p=0.004^{b}$} & \multicolumn{4}{|c|}{$\mathrm{p}=0.38^{\mathrm{c}}$} \\
\hline Poorest & 4985 & 355 & 7.1 & $1.37(1.11 ; 1.68)$ & 7788 & 231 & 3.0 & $1.59(1.21 ; 2.08)$ & 8203 & 35 & 0.4 & $1.07(0.68 ; 1.68)$ \\
\hline $2^{\text {nd }}$ & 3243 & 218 & 6.7 & $1.29(1.03 ; 1.61)$ & 5772 & 194 & 3.4 & $1.80(1.35 ; 2.39)$ & 7545 & 37 & 0.5 & $1.23(0.80 ; 1.88)$ \\
\hline Schooling (yr) ${ }^{\mathrm{a}}$ & \multicolumn{4}{|c|}{$p=0.01^{b}$} & \multicolumn{4}{|c|}{$p<0.001^{b}$} & \multicolumn{4}{|c|}{$\mathrm{p}=0.002^{\mathrm{c}}$} \\
\hline$\leq 4$ & 2167 & 159 & 7.3 & $1.32(1.05 ; 1.66)$ & 4581 & 139 & 3.0 & $1.70(1.29 ; 2.23)$ & 7380 & 28 & 0.4 & $1.19(0.70 ; 2.04)$ \\
\hline $5-8$ & 2020 & 157 & 7.8 & $1.40(1.12 ; 1.75)$ & 3859 & 149 & 3.9 & $2.16(1.63 ; 2.95)$ & 7329 & 41 & 0.6 & $1.76(1.08 ; 2.85)$ \\
\hline $9-11$ & 5393 & 375 & 7.0 & $1.25(1.04 ; 1.50)$ & 8782 & 256 & 2.9 & $1.63(1.27 ; 2.10)$ & 14140 & 91 & 0.6 & $2.02(1.34 ; 3.04)$ \\
\hline$\geq 12$ & 2682 & 149 & 5.6 & Reference (1) & 3969 & 71 & 1.8 & Reference (1) & 10362 & 33 & 0.3 & Reference (1) \\
\hline Color/ethnicity & \multicolumn{4}{|c|}{$p<0.001^{c}$} & \multicolumn{4}{|c|}{$\mathrm{p}=0.01^{\mathrm{c}}$} & \multicolumn{4}{|c|}{$p=0.002^{*}$} \\
\hline
\end{tabular}

Source: prepared by authors from the results.

a Subjects $<20$ years were excluded as most were still at school.

${ }^{b}$ test for linear trend

test for heterogeneity

\section{DISCUSSION}

Our study is the largest population-based serological survey for antibodies against SARS-CoV-2 in low- and middleincome countries, and only comparable to the national surveys carried out in Spain (4). Our findings show that the COVID-19 pandemic is hitting harder at the poorest and disadvantaged groups in Brazil. The proportions of individuals with positive tests was higher among indigenous, black and brown subjects compared to whites, as well as being inversely associated with socioeconomic position.

Concerning ethnic inequalities in health and nutrition in Brazil, several studies have reported that indigenous children and adolescents show higher mortality than other ethnic 
TABLE 4. Prevalence ratio of antibodies against SARS-CoV-2 according to color/ethnicity

\begin{tabular}{|c|c|c|c|}
\hline \multirow[b]{2}{*}{ Color/ethnicity } & \multicolumn{3}{|c|}{ Prevalence ratio $(95 \% \mathrm{CI})$} \\
\hline & Unadjusted & Adjusted for region & $\begin{array}{l}\text { Adjusted for region } \\
\text { and wealth quintiles }\end{array}$ \\
\hline & $\mathrm{p}<0.001^{\mathrm{a}}$ & $p<0.001^{a}$ & $p<0.001^{a}$ \\
\hline White & Reference (1) & Reference (1) & Reference (1) \\
\hline Brown & $2.69(2.39 ; 3.02)$ & $1.46(1.30 ; 1.65)$ & $1.43(1.27 ; 1.62)$ \\
\hline Black & $2.17(1.86 ; 2.53)$ & $1.35(1.16 ; 1.58)$ & 1.32 (1.13; 1.54) \\
\hline Asian & $1.85(1.38 ; 2.48)$ & $1.10(0.82 ; 1.48)$ & $1.08(0.81 ; 1.45)$ \\
\hline Indigenous & $4.71(3.65 ; 6.08)$ & $2.25(1.74 ; 2.91)$ & $2.17(1.68 ; 2.81)$ \\
\hline
\end{tabular}

Source: prepared by authors from the results.

Source: prepared by author
a test for heterogeneity

groups (11), and that similar gaps are also observed for adult mortality (12). Indeed, there is overwhelming evidence that indigenous populations have been left behind when health conditions improved in Brazil in the recent past (13). It would be surprising if COVID-19 turned out to be different from other existing health conditions.

It has been reported that COVID-19 is hitting hard at rural indigenous villages in reservations (14), but there are no comparisons with other ethnic groups. As mentioned in the Introduction, Baqui et al (5) found that COVID-19 hospital case-fatality was higher among individuals classified with black and with mixed ancestry, compared to whites. This study was based on a public dataset on hospitalizations and only a few subjects were identified as indigenous, and for this reason the case fatality among them was not estimated (5).

Because the magnitude of the association of seroprevalence for COVID-19 and skin color decreased after controlling for region of the country, the five-fold difference observed in antibody prevalence between indigenous and white subjects had been partly inflated by place of residence. Yet, even after adjustment for region, indigenous individuals were about twice as likely as whites to present antibodies against SARS-CoV-2, and in the national analyses including adjustment for region of the country and socioeconomic status, the prevalence ratio remained at around two.

The interpretation of these analyses suggests that indigenous subjects were at substantially higher risk than other ethnic groups. This was partly due to the fact that they were concentrated in the Amazon region, where prevalence was the highest in the country at the time of the surveys, and also because their living standards were the lowest when compared to other groups. Nevertheless, their increased risk persisted in the stratified and adjusted analyses for socioeconomic status. Future studies will need to investigate the mechanisms behind this association.

In terms of ethnicity, the "brown" or "pardo" category had the second highest prevalence among the five groups. This category includes individuals who self-report has having mixed ancestry. Genomic ancestry studies (15) show that in the Northern city of Belém self-classified brown individuals had, on average, 69\% European ancestry, followed by 21\% Amerindian ancestry and $11 \%$ African ancestry, while in the South they had on average $44 \%$ European, $11 \%$ Amerindian and $45 \%$ African ancestries. Therefore, the evidence suggests that brown subjects in the North -among whom seroprevalence was $7.1 \%-$ were genetically closer to Amerindians than was the case for the same group in other parts of the country.
With respect to the study limitations, the use of rapid serological tests for clinical decision-making and for defining individuals as immune to COVID-19 has been criticized. But the use of such tests to estimate the seroprevalence is much less controversial, provided the test has been validated $(16,17)$. The rapid test used in our study (Wondfo SARS-CoV-2 antibody test) underwent different validation studies using RT-PCR as the gold standard, including one carried out by our own team. These studies estimated the test's sensitivity and specificity at $84.8 \%$ and $99.0 \%$, respectively. It has been suggested that using capillary blood to estimate seroprevalence tends to increase the rate of false negative results (18); however, this finding has not been replicated by other studies (19). Furthermore, our validation study (8) used capillary blood and the observed sensitivity was similar to that reported in another studies. Therefore, this should not be considered as a main study limitation as all population subgroups should be affected. Recent evidence suggests that antibody levels against SARS-CoV-2 fall rapidly over a few weeks, regardless of the type of test used (20); therefore, our results correspond to relatively recent infections rather than cumulative prevalence. Again, all population subgroups are likely to be similarly affected.

The restriction of the sample to sentinel sites that are the larger and more developed cities should not be considered as a major limitation, as we are not trying to estimate the prevalence of the infection in the whole country, but its association with socioeconomic and demographic characteristics.

Due to logistic difficulties including a massive fake news campaign through social media, it was not possible to complete the first round of the study in 87 cities, so that the sample size was 25025 instead of the planned 33250 tests. These difficulties were overcome in the next two rounds, when the intended sample size was nearly achieved.

Concerning selection bias, the response rates of around $54 \%$ are similar to that reported in the Spanish survey (59.5\%) and higher than achieved in national surveys in Iceland and Austria, both of which had response rates of about one third of the intended sample (21). The higher proportion of female in the studied sample could be due to the fact that males were less like to comply with the stay at home recommendations. The most frequent reason for non-response was the fact that the whole family was away from home when the visit took place, which may be associated with temporary moves to smaller towns or to rural area, as larger cities were more strongly hit by the pandemic in the early phases. Regarding indigenous populations, it should be noted that our sample was restricted to those living in urban areas. Lastly, our sample had fewer children than expected, which was probably due to their reluctance to undergo a finger prick when randomly selected within the household; in these cases, a second person was randomly selected and if that person also refused the household was replaced.

In summary, the analyses of the three waves of national serological surveys in Brazil showed important inequalities in the prevalence of antibodies against SARS-CoV-2 according to family wealth, education and ethnic groups. Contrary to the initial impressions that COVID-19 would strike all groups in Brazilian society with similar intensity, our analyses show that individuals from poor families and with little schooling were at higher risk of having been infected. In terms of ethnicity or skin color, whites had the lowest risk, whereas indigenous subjects and those with black or brown skin color were most affected (22). 
Authors' contributions. BLH, MFS, PCH, CGV conceived the study, analyzed the data, wrote/reviewed the manuscript. AJDB, FCB, FPH, MSD, AMBM contributed with data analysis, interpreted the results, and reviewed the manuscript. All authors reviewed and approved the final version.

Funding. The study was funded by the Brazilian Ministry of Health, Instituto Serrapilheira, Brazilian Collective Health Association and the JBS SA initiative Fazer o Bem Faz Bem. The sponsors did not influence in any way the design, the data collection, the analysis, the writing, and the decision to publish these results.

Conflict of interests. None declared.

Disclaimer. Authors hold sole responsibility for the views expressed in the manuscript, which may not necessarily reflect the opinion or policy of the RPSP/PAJPH and/or PAHO.

\section{REFERENCES}

1. Marmot M. Society and the slow burn of inequality. Lancet. 2020;395(10234):1413-14. doi:10.1016/s0140-6736(20)30940-5

2. de Lusignan S, Dorward J, Correa A, et al. Risk factors for SARSCoV-2 among patients in the Oxford Royal College of General Practitioners Research and Surveillance Centre primary care network: a cross-sectional study. Lancet Infect Dis. 2020. doi:https:// doi.org/10.1016/S1473-3099(20)30371-6

3. Williamson EJ, Walker AJ, Bhaskaran K, et al. OpenSAFELY: factors associated with COVID-19 death in 17 million patients. Nature. 2020. doi:10.1038/s41586-020-2521-4

4. Pollán M, Pérez-Gómez B, Pastor-Barriuso R, et al. Prevalence of SARS-CoV-2 in Spain (ENE-COVID): a nationwide, population-based seroepidemiological study. Lancet. 2020. doi:10.1016/ S0140-6736(20)31483-5

5. Baqui P, Bica I, Marra V, Ercole A, van der Schaar M. Ethnic and regional variations in hospital mortality from COVID-19 in Brazil: a cross-sectional observational study. Lancet Glob Health. 2020. doi:10.1016/S2214-109X(20)30285-0

6. Ribeiro H, Lima VM, Waldman EA. In the COVID-19 pandemic in Brazil, do brown lives matter? Lancet Glob Health. 2020. doi:10.1016/S2214-109X(20)30314-4

7. Whitman JD, Hiatt J, Mowery CT, et al. Test performance evaluation of SARS-CoV-2 serological assays, 2020. (unpublished)

8. Pellanda LC, Wendland EM, McBride AJA, et al. Sensitivity and specificity of a rapid test for assessment of exposure to SARS-CoV-2 in a community-based setting in Brazil. medRxiv. 2020:2020.05.06.20093476. doi:10.1101/2020.05.06.20093476

9. Petrucelli JL, Saboia AL. Características étnico-raciais da população: classificação e identidades. Rio de Janeiro: Instituto Brasileiro de Geografia e Estatística (IBGE); 2013.

10. Barros AJ, Victora CG. A nationwide wealth score based on the 2000 Brazilian demographic census. Rev Saude Publica. 2005;39(4):523-9. doi:10.1590/s0034-89102005000400002

11. Campos MB, Borges GM, Queiroz BL, Santos RV. Differences in mortality between indigenous and non-indigenous persons in Brazil based on the 2010 Population Census. Cad Saude Publica. 2017;33(5):e00015017. doi:10.1590/10.1590/0102-311x00015017
12. Santos RV, Borges GM, Campos MB, et al. Indigenous children and adolescent mortality inequity in Brazil: What can we learn from the 2010 National Demographic Census? SSM Popul Health. 2020;10:100537. doi:10.1016/j.ssmph.2020.100537

13. Coimbra CEA, Santos RV. Emerging health needs and epidemiological research in indigenous peoples in Brazil. In: Salzano FM, Hurtado AM, editors. Lost paradises and the ethics of research and publication. Oxford: Oxford University Press; 2004. p. 89-109.

14. Jardim PdTC, Dias IMÁV, Grande AJ, et al. COVID-19 experience among Brasil s indigenous people. Rev Assoc Med Brasil. 2020;66:861-63

15. Pena SD, Di Pietro G, Fuchshuber-Moraes M, et al. The genomic ancestry of individuals from different geographical regions of Brazil is more uniform than expected. PLoS One. 2011;6(2):e17063. doi:10.1371/journal.pone.0017063

16. Bryant JE, Azman AS, Ferrari MJ, et al. Serology for SARS-CoV-2: Apprehensions, opportunities, and the path forward. Sci Immunol. 2020;5(47). doi:10.1126/sciimmunol.abc6347

17. Theel ES, Slev P, Wheeler S, et al. The Role of Antibody Testing for SARS-CoV-2: Is There One? J Clin Microbiol. 2020. doi:10.1128/ jcm.00797-20

18. Santos VAD, Rafael MM, Sabino EC, Duarte A. Sensitivity of the Wondfo One Step COVID-19 test using serum samples. Clinics (Sao Paulo). 2020;75:e2013. doi:10.6061/clinics/2020/e2013

19. Black MA, Shen G, Feng X, et al. Analytical performance of lateral flow immunoassay for SARS-CoV-2 exposure screening on venous and capillary blood samples. medRxiv. 2020:2020.05.13.20098426. doi:10.1101/2020.05.13.20098426

20. Ibarrondo FJ, Fulcher JA, Goodman-Meza D, et al. Rapid Decay of Anti-SARS-CoV-2 Antibodies in Persons with Mild Covid-19. N Engl J Med. 2020;383(11):1085-87. doi:10.1056/NEJMc2025179

21. Gudbjartsson DF, Helgason A, Jonsson H, et al. Spread of SARSCoV-2 in the Icelandic Population. N Engl J Med. 2020. doi:10.1056/ NEJMoa2006100

22. Victora CG, Barreto ML, Leal MC, et al. Health conditions and health-policy innovations in Brazil: the way forward. Lancet. 2011;377:2042-53 


\section{Prevalencia de anticuerpos contra el SARS-CoV-2 según el estatus socioeconómico y étnico en una encuesta nacional de Brasil}

RESUMEN Objetivos. Investigar las desigualdades socioeconómicas y entre distintos grupos étnicos en la prevalencia de anticuerpos contra el SARS-CoV-2 en las 27 unidades federativas del Brasil.

Métodos. En este estudio transversal, se realizaron tres encuestas de hogares los días 14-21 de mayo, 4-7 de junio y 21-24 de junio, 2020 en 133 áreas urbanas brasileñas. Se utilizó un muestreo de etapas múltiples para seleccionar 250 individuos en cada ciudad a fin de someterlos a una prueba rápida de anticuerpos. Los sujetos respondieron un cuestionario sobre los bienes del hogar, la escolaridad y el color de la piel/etnia (autodeclarado utilizando la clasificación brasileña estándar de cinco categorías: blanco, negro, pardo, asiático o indígena). Se utilizó el análisis de los componentes principales de los bienes para clasificar la posición socioeconómica en cinco quintiles de riqueza. Se empleó la regresión de Poisson para los análisis.

Resultados. Se analizaron 25025 sujetos en la primera encuesta, 31165 en la segunda y 33207 en la tercera, que mostraron una prevalencia de resultados positivos de 1,4\%, 2,4\% y 2,9\% respectivamente. Los individuos del quintil más pobre tuvieron 2,16 veces más probabilidades de presentar un resultado positivo (intervalo de confianza del 95\% 1,86; 2,51) que los del quintil más rico, y los que tenían 12 o más años de escolaridad tuvieron una prevalencia menor que los sujetos con menos educación. Las personas indígenas presentaron una prevalencia $4,71(3,65 ; 6,08)$ veces mayor que las blancas, al igual que las de piel negra o parda. El ajuste por región del país redujo los índices de prevalencia según la riqueza, la educación y el origen étnico, pero los resultados siguieron siendo estadísticamente significativos.

Conclusiones. La prevalencia de anticuerpos contra el SARS-CoV-2 en el Brasil muestra gradientes relacionados con la posición socioeconómica y la etnia muy pronunciados, con menor riesgo en las personas blancas, educadas y ricas.

Palabras clave Epidemiología; infecciones por coronavirus; encuestas y cuestionarios; inequidad social; Brasil.

\section{Prevalência de anticorpos contra o SARS-CoV-2 de acordo com o status socioeconômico e étnico em uma pesquisa nacional no Brasil}

RESUMO

Objetivos. Investigar as desigualdades socioeconômicas e étnicas na prevalência de anticorpos contra SARS-CoV-2 nas 27 unidades federativas do Brasil.

Métodos. Neste estudo transversal, três pesquisas domiciliares foram realizadas de 14 a 21 de maio, 4 a 7 de junho, e 21-24 de junho, 2020 em 133 áreas urbanas brasileiras. Amostragem em várias etapas foi utilizada para selecionar 250 indivíduos em cada cidade para se submeter a um teste rápido de anticorpos. Os sujeitos responderam a um questionário sobre bens domésticos, escolaridade e cor da pele/etnicidade (auto-relatada utilizando a classificação padrão brasileira de cinco categorias: branco, preto, pardo, asiático ou indígena). A análise dos componentes principais dos ativos foi utilizada para classificar a posição socioeconómica em cinco quintis de riqueza. A regressão de Poisson foi utilizada para as análises.

Resultados. 25025 indivíduos foram testados na primeira pesquisa, 31165 na segunda, e 33207 na terceira, com prevalência de resultados positivos de 1,4\%,2,4\% e 2,9\%, respectivamente. Indivíduos no quintil mais pobre tinham 2,16 vezes (intervalo de confiança de 95\% 1,86; 2,51) mais probabilidade de ter um resultado positivo do que aqueles do quintil mais rico, e aqueles com 12 ou mais anos de escolaridade tinham uma prevalência menor do que aqueles com menos educação. Os indivíduos indígenas tinham 4,71 $(3,65 ; 6,08)$ vezes mais prevalência do que os brancos, assim como aqueles com cor da pele preta ou parda. $\mathrm{O}$ ajuste regional reduziu as taxas de prevalência de acordo com a riqueza, educação e etnia, mas os resultados permaneceram estatisticamente significativos.

Conclusões. A prevalência de anticorpos contra a SARS-CoV-2 no Brasil mostra gradientes relacionados com a posição socioeconómica e a etnia muito acentuados, com os menores riscos entre os indivíduos brancos, educados e ricos.

Palavras-chave Epidemiologia; infecções por coronavirus; inquéritos e questionários; iniquidade social; Brasil. 